\title{
A Theoretical Overview of the Stockout Problem in Retail: from Causes to Consequences
}

Due to the relevance of stockouts in the retail sector together with their significantly negative effect both on retail and the whole supply chain, this paper offers a theoretical review of the stockout definition, rates, its main causes and consequences.

Keywords: stock out, out of stock, stockout rates, stockout causes, stockout consequences.

Atsižvelgiant ị prekių trūkumo lentynose svarbą mažmeninëje prekyboje ir reikšmingą neigiamą poveikị tiek mažmeninei prekybai, tiek visai tiekimo grandinei, šiame straipsnyje pateikiama prekių trūkumo lentynose sampratos, apimties, pagrindinių priežasčių bei pasekmių teorinė apžvalga.

Raktiniai žodžiai: prekių trūkumas lentynose, prekių trūkumo lentynose apimtis, prekių trūkumo lentynose priežastys, prekių trūkumo lentynose pasekmès.

\section{Introduction}

According to Efficient Consumer Response (2003), stockout is a situation, when a product is not found in the desired form, flavour or size, not found in saleable condition, or not shelved in the expected location. Stockouts in the retail sector have been widely analysed by both researchers and practitioners. Though it is not a new topic, research is still relevant due to stockout rate has been stable for almost forty years and it continues to be a key problem for many retailers. In fact, it is estimated that the European Grocery Industry losses due to stockouts reach 400 billion euros every year (Efficient Customer Response, 2003), worldwide benchmark average is 3,9 percent sales loss in retail (Corsten, Gruen, 2003).

High level of stockouts, which have caused millionaire losses to retail companies induce to take stockouts as a very important issue that should be investigated. First, it is necessary to begin by analysing the concept and its main characteristics. Knowing the concept, appropriate measures can be adjusted, and new research

Lidia SANCHEZ-RUIZ - PhD, assistant professor at Business and Management Department, Faculty of Economics and Management, University of Cantabria, Spain. Address: Facultad CCEE y Empresariales, Av. Los Castros s/n, 39005, Santander, Cantabria, Spain. Phone: +34942201061. E-mail: sanchezrl@unican.es

Beatriz BLANCO - PhD, associate professor at Business and Management Department, Faculty of Economics and Management, University of Cantabria, Spain. Address: Facultad CCEE y Empresariales, Av. Los Castros s/n, 39005, Santander, Cantabria, Spain. Phone: +34942201897. E-mail: blancob@unican.es

Asta KYGUOLIENE - PhD, associate professor at Marketing Department, Faculty of Economics and Management, Vytautas Magnus University, Lithuania. Address: K. Donelaičio str. 58, LT-44248, Kaunas, Lithuania. Phone: +370 37 327856. E-mail: asta.kyguoliene@vdu.lt 
gaps identified. Thus, the problem of research encompasses understanding the extent of stockouts in retail, identifying the causes and the consequences of stockouts.

The object of research is the stockout in retail.

The aim of this paper is to carry out a general review of the stockout problem in the retail sector. According to S. U. Kucuk (2008), stockout situations can be seen from two different angles: consumer behaviour and distribution. One leads to reasons, why stockouts happen; the other one to consequences, what effect stockouts may have on consumer. Similarly, the Efficient Consumer Response (2003) distinguishes two important angles: measurement stockout rates in stores and consumer response. Specifically, and taking into consideration the above-mentioned perspectives, the stockout concept will be analysed together with the stockout rates, the main causes and the main consequences.

In order to fulfil this objective, the method of literature analysis of the main studies published on the topic has been carried out. Also, to identify the main references on this topic, a specific search was carried out in different databases with the keyword "stockout", as well as its derivatives "stock out" or "out of stock".

\section{Stockout definition}

Seeking to analyse the stockout problem in retail, first of all, it is important to understand that the stockout meaning is not one-sided. J. C. F. Ehrenthal, T. W. Gruen, J. S. Hofstetter (2014) define a stockout situation when demand for an inventory item outplaces supply and the need for the item cannot be fulfilled. According to Efficient Consumer Response (2003), a stockout is a situation, when product is not found in a desired form, flavour or size, not found in saleable condition, or not shelved in the expected location.

The essence is when it is stated that the stockout situation appears. It might be stated that stockout situations happen when there are no inventories of SKU (stock-keeping unit) in the store, and inventories are equal to zero. Another attitude, which is more sensitive, considers that stockout situations appear when there is no product on the shelf. Customers do not care whether there are inventories in backroom if they are not accessible to them. In such situation customers experience stockouts, and it does not matter that there is stock in the backroom. R. Moorthy, S. Behera and S. Verma (2015) name it as a shelf out of stock - the condition when product is available in inventory, but is not present in the shelf, when the customer is looking for it. Shelf stockouts occur more frequently than store stockouts and it is rather difficult to capture (Papakiriakopoulos, 2006).

How companies interpret stockouts in practise often depend on the possibility to register stockouts. If there are no possibilities to "see" what products are available on the shelf at the current moment, companies often choose to register stockouts only when there are zero inventories in the database. This choice is the easiest one, but it does not correctly reflect what stockouts mean to customers. The more correct way it would be to understand stockouts as the situation when there is no product on the 
shelf. In fact, organizations which want to provide better customer service state that stockouts are the situations when there is no product on shelf; some of them measure stockouts once/twice a day, before/ after the peak hours or invest into information technologies which allow them to count stockouts in real time, this way having the most correct view and meaning of stockouts. L. Holman, G. Buzek (2008) go deeper and explain stockout deeper. They define 5 stockout situations: empty shelf; stock present but no help available; stock present but no access; promo price mismatched (the consumer does not make the purchase because the price/offer in the store does not match advertised); and any other reasons because of which consumer decides to leave the store and not buy desired product.

Stockout might be permanent and temporary. Temporary out of stock is considered as SKU being not available at the time customer is shopping, but it will be available at a later time. A temporary stockout can be made recognizable to customers through the empty shelves and the labels remaining on the shelves (Verbeke, Farris, Thurik, 1998). If the SKU will not be available later, it is considered as permanent stockout.

\section{Stockout rates}

Most studies state that managers are trying to reduce the number of stockouts as much as possible (Efficient Consumer Response, 2003; Corsten, Gruen, 2003). Nevertheless, according to different research studies, stockout rates in retail are still high and stockout rates change very slightly over time. In fact, according to E. Quirino des Sampaio, M. Sampaio (2016), the rates reported from J. O. Peckham (1963) are quite similar to the ones stated by Efficient Consumer Response (2003) forty years later. J. O. Pecham (1963) indicated that the rates of stockout equalled to 8.5 percent, Efficient Consumer Response (2003) after forty years -7.1 percent. More recent studies share the obtained similar results. For instance, according to C. Metzger et al. (2007), the retail industry faces stockout rates of 5-10 percent. J. Aastrup, H. Kotzab (2010) summarize that the average retail stockout rates are about 8 percent. L. Holman, G. Buzek (2008) argue that true out of stock rates are much higher than these provided. Particially because of the use of a more expanded definition of stockout items, they calculate stockouts equal to 17.8 percent (Grubor, Milicevic, Djokic, 2017). Such a rate of stockout indicates that stockout problem in retail is still relevant and still needs investigation.

From the geographical point of view, D. Consten, T. Gruen (2005) state that stockouts are quite similar in different regions: Europe - 8.6 percent, USA 7.9 percent, other regions -8.2 percent, worldwide -8.3 percent. Nonetheless, dividing Europe to Northwest Europe (Norway, Denmark, Sweden, France, Belgium, Netherlands, Germany, Switzerland, Austria, United Kingdom, Finland) and Southeast Europe (Portugal, Spain, Greece, Poland, Hungary, Slovakia, Check Republic), some differences could be seen. Thus, Southeast Europe demonstrates higher stockouts (10.8 percent) comparing to Northwest Europe (7.2 percent). 
According to T. Gruen, D. Corsten, S. Bharadwaj (2002) research, there are some peculiarities in stockout rates. Stockout rates vary between categories, the worst performing category reaches 15-16 percent and the best - only 1 percent. Fast moving items have 50-80 higher stockout rates versus all products (1315 percent comparing to 8,3 percent average), the top 10 percent of the fastest moving items account for 45 percent of the stockouts. Promoted items have higher stockout rates comparing to non-promoted, demonstrating a ratio of $2: 1$. The duration of out of stock by descending order is as follows: 1-3 days (36 percent), 8 hours - 1 day (25 percent), 8 hours or less (20 percent), 3 days or more (19 percent). According to J. Fernie, D. B Grant (2008), there are higher stockout rates in small convenience stores as compared to supermarkets and, similarly, hypermarkets stockout rates have been lower than the ones of supermarkets (Aastrup, Kotzab, 2009). Finally, it could be said that stockout rates are higher later at the day, lower early at the day, with a peak at Sunday and Monday and lowest rates on Saturday (Gruen et al., 2002).

\section{Stockout causes and antecedents}

According to J. Aastrup and H. Kotzab (2009), the stockout root causes can be grouped into in store causes (store ordering and replenishment) and out of store causes. Research shows that 70-90 percent of stockout situations arise at the store level (Corsten, Gruen, 2003, Efficient Consumer Response, 2003).
According to T. Gruen et al. (2002), there are 3 groups of stockout causes:

1. Retail store ordering and forecasting;

2. Retail store shelving and replenishement practices in which the product is at the store, but not on the shelf;

3. Combined upstream causes.

Retail store ordering and forecasting is the main reason, about one half of stockout - 47 percent, where items being in store but not on shelf - 25 percent, total upstream causes - 28 percent. Based on Efficient Consumer Response (2003), the distribution of causes is as follows: 35 percent arise from store ordering and forecasting, 12 percent - from store replenishment, 11 percent - from inventory accuracy, 30 percent - from delisting by store staff, 12 percent - from other reasons.

Looking deeper to the replenishment process, it is important to mention, that the staff related issues strongly influence the shelf availability. Collecting information of forty years, J. Aastrup and H. Kot$\mathrm{zab}$ (2010) state that the shelf service level "decreases at about 5-6 percent in store, what seems as a threatening outcome. The importance of shelf replenishment issues, often called as last 50 yards problem, is proved by D. Corsten and T. Gruen (2003), and J. Fernie and D. B. Grant (2008).

J. Aastrup and H. Kotzab (2009) state that in store causes directly affect stockout situations, but there are causes, which indirectly affect the stockout situation. Indirect causes are: management emphasis, organizational conditions and planning, allocation of space... They affect the store ordering and store replenishment tasks, this way having impact on stockout. Store size with organizational, space and 
turnover preconditions also have indirect effect of stockouts, as space is a limiting factor. Besides, high product variety and inventory levels may cause stockouts as well, by increasing the stock which is in the store but not on the shelves (Ton, Raman, 2010).

L. H. R. Vasconcellos and M. Sampaio (2009) in their research are more detailed and indicate much more stockout causes, for instance: supplier delays, insufficient shelf space, supplier does not deliver the order correctly, supplier does not have the product available, store orders incorrectly, shelf is not refilled by a promoter (the product is on the storage shelf), merchandise is badly positioned on the shelf, merchandise is badly positioned in the storeroom, store takes too long to order, inventory error (difference between the physical and the accounting), lack of professionals to adequately refill the shelves, parameter errors of the shelf refilling system, buying centre is negotiating with the supplier. Some previous research that took place in Brazil, based on the results of retailers, concluded that the main reasons for stockout in compact supermarkets are supplier's delay and insufficient shelf space; in conventional supermarket - supplier's delay, mistakes in supplier's delivery, product unavailability from supplier, not replenished shelf and too long order time from the store; finally, the main causes for supermarkets are suppliers delay and mistakes in supplier's delivery.

D. Corsten and T. Gruen (2003) provide the root causes of stockouts following three general processes: ordering, replenishing and planning, excluding them according to intermediaries' type. Defining the root causes at different intermediaries' levels it is important to understand how each intermediary effect finally reflects at the store. At the store level, stockout during planning process may arise because of incongruence between shelf capacity and replenishment frequency, product purchasing frequencies, or large number of SKUs in assortment. Replenishing causes at store level are such as insufficient or busy staff; congested backroom; receiving errors; inaccurate records; infrequent, late or no shelf filling; bad execution of planogram; bad compliance with planogram; shrinkages like damages, or theft. Distribution centre as well may be the influencer of stockouts. During the replenishing process at distribution centre level transportation, including shipping and loading, loading errors, inaccurate records, storage, infrequent, late or no replenishment, long and infrequent lead times, shrinkage may lead to out of stock. At the wholesaler/retail headquarter level, the main causes, affecting out of stock appear during the planning process. They are as follows: new or discontinued items, data and communication, planogram design and implementation, promotions and pricing decisions, advertising and display planning, store layout and service levels. Availability (shortage) is mentioned as one cause having impact on out of stock during replenishment process at the wholesaler/ retail headquarter level. The last level is supplier's level. During the planning process new or discontinued item, data and communication, promotions and pricing, advertising and display planning may lead to stockouts, while during replenishment - availability (packaging, raw materials and ingredient). Besides planning 
and replenishment processes D. Corsten, T. Gruen (2003) distinguish ordering process. During the ordering process the causes of out of stock are the same at all levels (store, distribution centre, wholesaler/retail headquarter, supplier): bad POS data, inaccurate records, inaccurate forecast, long cycles, inaccurate inventory, there can be no order or delayed, wrong order what may lead to out of stock.

\section{Stockout consequences}

When analysing stockout consequences, first it should be noted that stockouts lead to several effects. The most obvious result of stockouts are financial losses. Customer behaviour in a short and/or long term is another indicator what a powerful effect the stockout may have. Customers always want to have the right product at the right time in the right place. Stockouts reduce customer service and result in product, brand, category even store switching, because customers due to stockouts delay or cancel their purchase. Stockouts cause negative emotions: customers feel annoyed and frustrated. Also, it should be noted that stockouts affect loyalty to the store, attitude to the brand and the store.

\section{Consumer response to stockouts}

According to T. Gruen et al. (2002), there are 5 primary responses that consumers make when encountering stockouts for an SKU they had intended to purchase:

1. Buy item at another store (store switch);

2. Delay purchase (buy later at the same store);
3. Substitute - same brand (for a different size or type);

4. Substitute - different brand (brand switch);

5. Do not purchase the item, leave the store (lost sale).

Other researches are not so detailed and state, that stockouts evoke one of three main behaviours (Dadzie, Winston, 2007):

$\mathrm{S}$ - consumers buy a substitute item a different size, model or colour of the same item or a competitive brand item;

D - consumers delay the purchase decisions;

$\mathrm{L}$ - consumers leave the store.

Based on possible consumer reactions, consumer response to stockouts is called by the acronym SDL or SDL model.

L. H. R. Vasconcellos and M. Sampaio (2009) summarize 12 different research of various scholars published from 1963 to 2005, which analysed consumer response to stockouts. While conducting the research, exit survey, survey and field experiment were used. There is one obvious conclusion, which is the same in all research - the most common consumer behaviour is to substitute. One extremum of these research indicates that 83 percent of consumers substitute (Walter, Grabner, 1975), another one - 22 percent of consumers substitute (Schary, Christopher, 1979). All other analysed research, excluding extremums, allow to make the conclusion, that 40-62 percent of consumers substitute. Based on the same research overview, the second most common behaviour is to leave the store. Extremums of leaving behaviour are 48 percent, indicated by P. B. Schary, M. Christopher (1979) and 14 percent provided by C. K. Walter, 
J. R. Grabner (1975). Excluding extremums research results it can be stated that from 17 to 39 percent of consumers choose to leave. Delaying purchase is in the third place, research results indicating delaying purchase vary from 15 to 30 percent.

According to T. Gruen et al. (2002), the most common behaviour in the world, according to the world average is buying an item at another store (31 percent). Substituting different brand -26 percent and the same brand -19 percent, delaying purchase - 15 percent, leaving the store 9 percent. Differences among USA, Europe and other regions are presented in Table 1. The European behaviour is different from the world average, USA and other regions. The Europeans' main behaviour is to substitute different brand (32 percent) and in the second place - to buy an item at another store (27 percent).

Efficient Consumer Response (2003) state that 21 percent of customers buy the item at another store, 17 percent delay their purchase, 16 percent substitute with the brand, 37 percent substitute to another brand, 9 percent leave the store.

Consumer response to the stockout might vary according to other variables. Some researchers found that store loyal customers would rather postpone buying, though W. Verbeke et al. (1998) state, that customers, who were classified as store loyals, where more likely to switch stores in response to stockouts. W. Verbeke et al. (1998) found that customers whose expenditure per shopping trip was low were more likely to postpone the purchase than to switch. Consumer behaviour depends on the nature of goods (Kucuk, 2008). Based on T. Van Woensel et al. (2007) research, there can be drawn a conclusion, that substitution rates for perishable products are significantly higher, customers often shift to other brands when shopping for products that could be easily substituted (Hausruckinger, Hasse, 2003). According to European Consumer Response (2003), impulse items, less involvement, more substitutability and less brand loyalty increase the likelihood of substitution purchases. Strong brand loyalty, more planned purchases, higher involvement increases the likelihood of store switching.

There are many more antecedents, which determine what consumer response to stockout might be. The comprehensive model of antecedents of a stockout situation based mainly on literature review is provided by R. Helm, T. Hegenbart, H. Endres (2013). They state there are 4 groups of antecedents - product, store, consumer and situation related factors. Each group encompass related factors:

Table 1. Average consumer responses by region, in percent

\begin{tabular}{|l|c|c|c|c|}
\hline & World Average & USA & Europe & Other Regions \\
\hline Buy item at another store & 31 & 31 & 27 & 34 \\
\hline Delay purchase & 15 & 15 & 17 & 13 \\
\hline Substitute same brand & 19 & 21 & 16 & 20 \\
\hline Substitute different brand & 26 & 22 & 32 & 25 \\
\hline Leave the store & 9 & 11 & 9 & 8 \\
\hline
\end{tabular}

Source: T. Gruen et al. (2002). 
1.Product related factors - brand loyalty, product involvement, buying involvement, buying frequency, packaging sizes, item variants, acceptable alternatives, decision difficulty.

2. Store related factors - store loyalty, alternative stores.

3. Consumer related factors - price consciousness, quality consciousness, utilitarian shopping attitude, hedonic shopping attitude, risk taking, variety seeking, mobility, shopping frequency, age, gender.

4. Situation related factors - buying urgency, required quality, time pressure, shopping time, impulse buying.

R. Helm et al. (2013) proved that range of acceptable substitutes for stockout items has a greatest impact, prevents from store switching or cancellation, which are disadvantageous for retailers in terms of revenue loss. Among store related characteristics, store loyalty contributes to reduced chance of store switching. Hedonic shopping attitude, mobility and age significantly affect how customers react to stockouts. From situational factors, buying urgency and shopping time are extremely important.

\section{Lost sales}

Stockouts have a significantly negative effect on companies' revenues (Battista et al., 2011) and is related to lost sales (Corsten, Gruen, 2003). According to Efficient Consumer Response (2003), 9 percent of consumers who face a stockout situation cancel their purchase. The European grocery industry losses around 400 billion Euro every year due to stockouts. Worldwide the benchmark average is 3.9 percent sales loss at retail due to stockout items (Corsten, Gruen, 2003). Based on the mentioned scholars, the differences between regions are very small (Europe 3.7 percent, USA - 3.8 percent, other regions - 4 percent), bigger differences there are among categories - from 2.1 to 4.5 percent. Improvement of the stockouts situation can have a significant impact on sales - for retailer a 2 percent increase in on-shelf availability equals a 1 percent increase in sales (Mitchell, 2012).

Evidences from practice prove that taking actions to decrease lost sales is possible. A. Carey and J. Staniforth (2007) present results of an exit survey, which was done by House of Fraser company, which uncover that 36 percent of customers visiting House of Fraser, who planned to purchase, did not, because they did not find their size or colour. If half the customers who could not find stock were to purchase, sales would increase by $63 £$ million. After the company took actions to improve the situation, monthly sales increased by 9 percent.

Analysing stockouts from a position of retailer, it is important to note that not all stockouts lead to lost sales. According to Ch. Adusey, D. Awunyo-Vitor (2014), there are two clusters of consumer reactions: (1) buy a substitute, (2) not buying a substitute during the store visit. Only one reaction leads to lost sales. If consumer substitute the same brand for a different size or type or substitute a different brand, retailer still have sales. Delaying of purchase as well will result in sales, just incomes are delayed for some time. Not buying a substitute, i.e. switching the store and leaving the store are the two main reasons leading to lost sales, what means direct losses. According to T. Gruen et al. 
(2002), the most problematic option to the retailer is buying at another store.

\section{Decreased customer satisfaction, effect on store loyalty and store image, risk of consumer loss}

Stockouts lead not only to direct losses, i.e., financial losses, but they also lead to other consequences. A store with a higher overall stockout level will lose more customers and gain less customers from other stores (Corsten, Gruen, 2003). If a retailer is steadily having stockouts, first of all, it affects the overall reliance on the retailer. Customers want their item on the right time at the right place. If they do not manage to find their items, overall reliance on the retailer decreases.

Decreased customer satisfaction is one of the indirect losses. G. Fitzsimons (2000) state that stockouts negatively affect consumers' evaluation of their decision experience and thus lowers decision satisfaction. M.L. Fisher, J. Krishnan, S. Netessine (2006) identifies stockouts as the most important factor leading to customer satisfaction in US retail chain and vice versa A. Grubor et al. (2017) state that stockout leads to dissatisfaction. A. Musalem et al. (2010) and E. Breugelmans et al. (2006) also agree that stockouts decrease satisfaction.

Another issue concerns consumers emotions. According to K. Olofsson (2006) most of the people feel very frustrated experiencing stockouts situation (France - 62 percent, Great Britain 59 percent, Germany - 51 percent, Spain - 43 percent), following by the ones who are little frustrated (France 29 percent, Great Britain - 33 percent,
Germany - 37 percent, Spain - 35 percent). There are few consumers who feel not very or not all frustrated.

Stockouts also have impact on store image. Almost forty years ago, P. B. Schary and M. Christopher (1979) found that consumers who encounter stockouts rate store image significantly lower than those who did not experience stockouts.

W. Zinn and P. C. Lui (2001) state that stockouts impact consumers' perception of merchandise quality, loss of consumer loyalty, negative word of mouth. A. Musalem et al. (2010) and E. Breugelmans et al. (2006) agree that stockouts decrease shopper loyalty. Moreover, R. East, K. Hammond and W. Lomax (2008) even discuss that stockouts should be included as a factor when calculating the impact of out of stock, especially in supermarkets, where shoppers are more extreme towards the negative word of mouth comparing to positive.

Consumers do not tolerate stockouts. According to T. Gruen et al. (2002), for the first time, 70 percent of consumers substitute a brand, 30 percent do not buy; for the second time the balance between substitution and not buying is 50/50, when situation repeats for the third time only 30 percent of consumer substitute a brand and 70 percent do not buy. The final loss is consumer loss (Gruen et al., 2002). Even though consumer switching rate is still undocumented, the annual cost of permanent shopper loss to competitors is estimated at USA 1 million \$ per every 200 shoppers (Gruen, Corsten, 2007). K. Campo, E. Gijsbrechts, P. Nisol (2000) state that because of stockout retailer can lose up to 14 percent of customers. 


\section{Supply chain inefficiency}

Scholars state that stockouts negatively affects stakeholders operating across the supply chain (Gruen, Corsten, 2007). According to T. Gruen et al. (2002), consumer behaviour caused by stockouts (switching, delaying, etc.) provides inaccurate picture to managers who seek to have the supply chain deliver accurate levels and mixes of products to retail shelves. Irregular "fill in", rush orders due to stockout situations cause logistics - fulfilment inefficiencies. It often leads to bullwhip effect, where small shifts or the retailer level become magnified further up the supply chain. Information inefficiency is created when the retailer's ordered quantities do not correctly reflect the pattern of the true customer demand. Bullwhip effect drives up costs through the supply chain (Corsten, Gruen, 2003; Quelch, Jocz, 2012). According to Ch. Adusei, D. AwunyoVitor (2014), stockouts distort demand and leads not only to inaccurate forecast, but during stockout situations employees spend considerable time trying to satisfy customer who enquire about stockout items.

\section{Conclusions}

As it was stated in the introduction section, the aim of this paper was to carry out a general review of the stockout problem in the retail sector. Specifically, the stockout concept was analysed together with the stockout rates, its main causes and consequences.

As for the concept, many authors have defined stockouts along the scientific literature. Despite the nuances, all the definitions share the idea that a stockout can be understood as the lack of a product at the point of sale. At this point, it is worth noting the existence of two perspectives. The first group of authors understands that the stockout exists when there is no product in the inventory (neither on the shelf, nor in the backroom warehouse) to respond to the customer's demand. Another group of authors considers that stockout is only when there is no product in the backroom warehouse. This differentiation is closely related to the problem of measurement. While it seems simple to detect an inventory shortage; the detection of lack of the product on the shelf is more difficult to measure. It is interesting not only to know when there is a lack of product on the shelf, but also how much time the product has been lacking and how long it has taken to replenish the shelf. All this information is extremely useful to identify the root causes of this problem and propose truly useful improvement actions. In this sense, a future line of research could analyse how the use of new technologies can help to control and reduce these problems.

The studies reviewed show that the frequency of stockouts is variable. While it is true that, in general, the stockout rate has remained stable in the retail sector (5$10 \%$ ), differences have been identified depending on various characteristics. Thus, the category of the product, the product rotation, the retail format (convenient stores, supermarkets or hypermarkets), the day of the week or even the time of the day could influence the frequency of the stockouts.

Regarding the causes, they might be classified as: in-store causes and out of 
store causes, being the first ones and the most common ones. Specifically, the most common causes identified in different studies (although with different percentages, the order is common) are: ordering and forecasting problems, replenishment practises and upstream causes. Throughout the literature, numerous factors that may affect one or another cause have been identified: allocation of space, store size, high product variety, supplier delays, insufficient shelf space, inventory error, or insufficient or busy staff are some of them.

On the other side, with regard to the stockouts' consequences, previous studies have stated that as a result of stockouts customer service is negatively affected, i.e., stockouts impact customers behaviour. This, in turn, causes financial losses, customers dissatisfaction, reduced brand and/or store loyalty.

Based on the review, some research questions have arisen. For instance, as it was mentioned before, the role of new technologies should be analysed. How can new technologies help managers to reduce both the number of stockouts and their effects?
In relation to new technologies, the area of research that is gaining relevance is online retailing. Given the particularities of this type of retail, it seems logical to think that the problem of stockouts in this environment has very specific characteristics that require a separate analysis of it.

In addition, from the point of view of the customer, it is necessary to continue analysing what changes occur in the behaviour of consumers when a stockout occurs. Likewise, it would be interesting to analyse if the effect is the same depending on the gender or age of the consumer, if there are differences in consumer response in different regions. This information would be useful for retailers that, depending on their target audience, could adapt the improvement actions to be carried out.

Finally, in case the measures carried out to reduce the frequency of stockouts fail, it would be interesting to know what actions can be implemented in order to compensate the client and avoid losing it in the face of future purchases. This perspective is seen as possible future research directions.

\section{References}

1. Aastrup, J., Kotzab, H. (2010). Forty Years of Out of Stock Research - and Shelves Are Still Empty // The International Review of Retail, Distribution and Consumer Research. Vol. 20, pp. 147-164. doi: 10.1080/09593960903498284.

2. Aastrup, J., Kotzab, H. (2009). Analyzing Out of Stock in Independent Grocery Stores: An Empirical Study// International Journal of Retail and Distribution management. Vol. 37, No. 9, pp. 765-789. doi: 10.1108/09590550910975817.

3. Adusei, Ch., Awunyo-Vitor, D. (2014). Determinants of Stock Out in Retail Shops in Ghana: Evidence from Kumasi Metropolis // Modern Economy. Vol. 5, No. 13, p. 1240-1252. doi: $10.4236 /$ me.2014.513115.
4. Mitchell, A. (2012). Improving on Shelf Availability. - White paper, Symphony IRI Group.

5. Battista, C., Falsini, D., Scarabotti, I., Schiraldi, M. M. (2011). Quantifying Shelf Out of Stock in Fashion and Apparel Retail Stores // Proceedings of the Conference "Breaking down the Barriers between Research and Industry”. Padova, 14-16 September 2011.

6. Breugelmans, E., Campo, K., Gijsbrechts, E. (2006). Opportunities for Active Stock Out Management in Online Stores: The Impact of the Stock Out Policy on Online Stock Out Reactions // Journal of Retailing. Vol. 82, No. 3, pp. 215-228. doi: 10.1016/j.jretai.2006.05.001. 
7. Campo, K., Gijsbrechts, E., Nisol, P. (2000). Towards Understanding Consumer Response to Stock Out // Journal of Retailing. Vol. 76, No. 2, pp. 219-242. doi:10.1016/ S0022-4359(00)00026-9.

8. Carey, A., Staniforth, J. (2007). Improving Availability at House of Fraser: Availability and Demand Planning. - Paper presented at the 2007 ECR UK Conference, London, 21 March.

9. Corsten, D., Gruen, T. (2003). Desperately Seeking Shelf Availability: An Examination of the Extent, the Causes, and the Efforts to Address Retail Out of Stocks // International Journal of Retail and Distribution Management. Vol. 31, No. 12, p. 605-617. doi: 10.1108/09590550310507731.

10. Corsten, D., Gruen, T. (2005). On Shelf Availability: An Examination of the Extent, the Causes and the Efforts to Address Retail Out of Stocks / In the Consumer Driven Electronic Transformation, ed. G. J. Doukidis and A. P. Vrechopoulos. - Berlin: Springer, pp. 131-149.

11. Dadzie, K. Q., Winston, E. (2007). Consumer Response to Stock Out in the Online Supply Chain // International Journal of Physical Distribution and Logistics Management. Vol. 37, No. 1, pp. 19-42. doi: 10.1108/09600030710723309.

12. East, R., Hammond, K., Lomax, W. (2008). Measuring the Impact of Positive and Negative Word of Mouth on Brand Purchase Probability // International Journal of Research in Marketing. Vol. 25, pp. 215-224. doi: 10.1016/j. ijresmar.2008.04.001.

13. Efficient Consumer Response (2003). ECR - Optimal Shelf Availability. Increasing Shopper Satisfaction at the Moment of Truth. Internet access: <https://www.gsl. ch/docs/default-source/prozesse-dokus/ ecr-europe-osa---optimal-shelf-availability. pdf?sfvrsn=ddc66297_2> [accessed April 6, 2018].

14. Ehrenthal, J. C. F., Gruen, T. W., Hofstetter, J. S. (2014). Value-Attenuation and Retail Out of Stocks: A Service-Dominant Logic Perspective // International Journal of Physical Distribution and Logistics Management. Vol. 44, pp. 32-57. doi: 10.1108/IJPDLM-02-2013-0028.

15. Fernie, J., Grant, D.B. (2008). On Shelf Availability: The Case of a UK Grocery Retailer // The International Journal of Logistics Management. Vol. 19, No. 3, pp. 293-308. doi: 10.1108/09574090810919170.

16. Fisher, M. L., Krishnan, J., Netessine, S. (2006). Retail Store Execution: An Empirical Study.
Internet access: <http://knowledge.wharton. upenn.edu/papers/1336.pdf> [accessed April $10,2018]$.

17. Fitzsimons, G. (2000). Consumer Response to Stockouts // Journal of Consumer Research. Vol. 27, No. 2, pp. 249-266. doi: 10.1086/314323.

18. Grubor, A., Milicevic, N., Djokic, N. (2017). The Impact of Store Satisfaction on Consumer Responses in Out of Stock Situations // Review of Business Management. Vol. 19, No. 66, pp. 520537. doi: $10.7819 /$ rbgn.v0i0.2436.

19. Gruen, T. W., Corsten, D. (2007). A Comprehensive Guide to Retail Out of Stock Reduction in the Fast-Moving Consumer Goods Industry. Internet access: < https://www.nacds.org/wpcontent/uploads/2017/02/Retail-Out-of-StockReduction.pdf $>$ [accessed April 17, 2018].

20. Gruen, T., Corsten, D., Bharadwaj, S. (2002). Retail Out of Stocks: a Worldwide Examination of Extent, Causes and Consumer Responses. Internet access: <http://itsoutofstock.com/ wp-content/uploads/2013/04/GMA_2002_Worldwide_OOS_Study.pdf> [accessed April $15,2018]$.

21. Hausruckinger, G., Hasse, F. (2003). Rooting out Out of Stocks // International Commerce Review: ECR Journal. Vol. 3, No. 1, pp. 69-71.

22. Helm, R., Hegenbart, T. Endres, H. (2013). Explaining Costumer Reactions to Real Stockouts // Review of Managerial Science. Vol. 7, No. 3, p. 223-246. doi: 10.1007/s11846-012-0079-8.

23. Holman, L., Buzek, G. (2008). What's the Deal with Out of Stocks? - Franklin: IHL Group.

24. Kucuk, S. U. (2008). Can Distribution Explain Double Jeopardy Patterns // International Journal of Retail and Distribution Management. Vol. 36, No. 5, pp. 409-425. doi: 10.1108/09590550810870120.

25. Metzger, C., Meyer, J., Fleisch, E., Tröster, G. (2007). Weight Sensitive Foam to Monitor Product Availability on Retail Shelves / In the Pervasive Computing. Pervasive 2007. Lecture Notes in Computer Science, ed. A. LaMarca, M. Langheinrich, K. N. Truong, Vol. 4480. Berlin: Springer, pp. 268-279.

26. Moorthy, R., Behera, S., Verma, S. (2015). On Shelf Availability in Retailing // International Journal of Computer Applications. Vol. 116, No. 23, pp. 47-51. doi: 10.5120/20296-2811.

27. Musalem, A., Olivares, M., Bradlow, E. T., Terwiesch, C., Corsten, D. (2010). Structural Estimation of the Effect of Out of Stocks // 
Management Science. Vol. 56, No. 7, p. 11801197. doi: $10.1287 / \mathrm{mnsc} .1100 .1170$.

28. Olofsson, K. (2006). On Shelf Availability, Making It Happen Together. - Paper presented at the 2006 ECR Europe Conference, Stockholm, 29-31 May.

29. Papakiriakopoulos, D. (2006). Automatic Detection of Out of Shelf Products in the Retail Sector Supply Chain. - PhD diss., Athens University of Economics and Business, Greece.

30. Peckham, J. O. (1963). The Consumer Speaks // Journal of Marketing. Vol. 27, No. 4.

31. Quelch, J. A., Jocz, K. E. (2012). All Business Is Local - Why Place Matters More Ever in a Global Virtual World. - New York: Portfolio/ Penguin.

32. Quirino Dias Sampaio, E., Sampaio, M. (2016). Managerial Response to Stockouts: The Effect of Remedies on Consumer Behaviour // Production. Vol. 26, No. 1, pp. 66-77. doi: 10.1590/0103-6513.156113.

33. Schary, P. B., Christopher, M. (1979). The Anatomy of a Stock Out // Journal of Retailing. Vol. 55, No. 2, p. 59- 67.

34. Ton, Z., Raman, A. (2010). The Effect of Product Variety and Inventory Levels on Retail Store Sales: A Longitudinal Study // Production and Operations Management. Vol. 19, No. 5, p. 546560. doi: 10.1111/j.1937-5956.2010.01120.x.
35. Van Woensel, T., Van Donselaar, K., Broekmeulen, R., Fransoo, J. (2007). Consumer Responses to Shelf Out of Stocks of Perishable Products // International Journal of Physical Distribution and Logistics Management. Vol 37, Issue 9, p. 704-714. doi: 10.1108/09600030710840822.

36. Vasconcellos, L. H. R., Sampaio, M. (2009). The Stockouts Study: An Examination of the Extent and the Causes in the Sao Paulo Supermarket Sector // Brazilian Administration Review, Curitiba. Vol. 6, No. 3, Art. 6, pp. 263-279. doi: 10.1590/S1807-76922009000300007.

37. Verbeke, W., Farris, P., Thurik, R. (1998). Consumer Response to the Preferred Brand Out of Stock Situation // European Journal of Marketing. Vol. 32, Issue 11/12, p.1008-1028. doi: 10.1108/03090569810243640.

38. Walter, C. K., Grabner, J. R. (1975). Stockout Models: Empirical Tests in a Retail Situation // Journal of Marketing. Vol. 39, No. 3, p. 56-68.

39. Zinn, W., Liu, P. C. (2001). Consumer Response to Retail Stockouts // Journal of Business Logistics. Vol. 22, No. 1, p. 49-71. doi: 10.1002/ j.2158-1592.2001.tb00159.x.

The paper submitted: May 10, 2018 Prepared for publication: June 29, 2018

Lidia SANCHEZ-RUIZ, Beatriz BLANCO, Asta KYGUOLIENĖ

PREKIỤ TRŪKUMO LENTYNOSE MAŽMENINĖS PREKYBOS SEKTORIUJE PROBLEMOS TEORINE் APŽVALGA: PRIEŽASTYS IR PASEKMĖS

\author{
S a n tra u a
}

Prekių trūkumo lentynose problema, plačiai analizuoja tiek mokslininkai, tiek praktikai. Nepaisant to, prekių trūkumo problema vis dar aktuali, nes prekių trūkumo lentynose apimtys yra daugiau ar mažiau stabilios jau 40 metų ir ši problema išlieka viena iš esminių mažmeninès prekybos sektoriaus problemu.

Šio darbo tikslas - atlikti prekių trūkumo lentynose mažmeninès prekybos sektoriuje problemos teorinę apžvalgą. Siekiant šio tikslo, straipsnyje analizuojama prekių trūkumo lentynose samprata, apimtis, pagrindinès priežastys ir pasekmès. Tyrimo metodu pasirinkta literatūros analizè.

Prekių trūkumo lentynose samprata nèra vienalytè, vieni prekių trūkumu lentynose traktuoja situacijas, kai prekių nèra lentynose, kiti - kai jų nèra parduotuvès sandèlyje. Nepaisant skirtingų sampratų, bendra prekių trūkumo lentynose problema gali būti suprantama kaip produkto trūkumas pardavimo vietoje.

Prekių trūkumo lentynose apimtys jau ilgą laiką santykinai yra stabilios, svyruojančios tarp 
5-10 proc. Pasaulio prekių trūkumo lentynose vidurkis yra 8,3 proc., tačiau galima pastebèti geografinių skirtumų, ypač lyginant Europos regionus. Šiaurès Europai būdingos mažesnès prekių trūkumo lentynose apimtys $-7,2$ proc., Pietų regionuose šis rodiklis siekia 10,8 proc. Taip pat pastebima, kad prekių trūkumui lentynose priklauso nuo pačios prekių kategorijos, pardavimų skatinimo, savaitès dienos, ir netgi dienos meto.

Prekių trūkumo lentynose priežastys dažniausiai skirstomos ị prekių užsakymo ir prognozavimo problemas, prekių papildymo problemas ir problemas, kylančias iš tiekimo grandinès veiksmų. Šios priežastys sąlygoja pasekmes, kurios pirmiausia suvokiamos kaip finansiniai nuostoliai - prarasti pardavimai. Tačiau ne mažiau svarbios pasekmès yra vartotojų atsakas i prekių trūkumą lentynose, kuris apima keletą galimų alternatyvų: nuo prekès pakaitalo įsigijimo toje pačioje parduotuveje iki to paties produkto issigijimo kitoje parduotuveje. Bet kuriuo atveju prekių trūkumas lentynose dažnai sąlygoja mažèjantị vartotojų pasitenkinimą, mažejantị lojalumą prekès ženklui ir (ar) parduotuvei, didina riziką prarasti vartotojus.

Remiantis atlikta analize, tolesnès galimos tyrimo kryptys apima informacinių technologiju igalinimo problemai spręsti analizę, prekių trūkumo elektroninèje erdvèje savitumų analizę, demografinių charakteristikų vertinimą, siekiant geriau pažinti vartotoją, lyginamąją vartotojų atsako i prekių trūkumus lentynose analizę tarp skirtingų šalių. 